\title{
C02 Huff-n-Puff Process in a Light Oil Shallow Shelf Carbonate Reservoir
}

\author{
Quarterly Report \\ April 1 - June 30, 1997 \\ By:
Scott Wehner; Mark Kovar
}

Work Performed Under Contract No.: DE-FC22-94BC14986

\author{
For \\ U.S. Department of Energy \\ Office of Fossil Energy \\ Federal Energy Technology Center \\ P.O. Box 880 \\ Morgantown, West Virginia 26507-0880
}

By

Texaco Exploration and Production Inc.

P. O. Box 3109

Midland, Texas 79702 


\section{Disclaimer}

This report was prepared as an account of work sponsored by an agency of the United States Government. Neither the United States Government nor any agency thereof, nor any of their employees, makes any warranty, express or implied, or assumes any legal liability or responsibility for the accuracy, completeness, or usefulness of any information, apparatus, product, or process disclosed, or represents that its use would not infringe privately owned rights. Reference herein to any specific commercial product, process, or service by trade

name, trademark, manufacturer, or otherwise does not necessarily constitute or imply its endorsement, recommendation, or favoring by the United States Government or any agency thereof. The views and opinions of authors expressed herein do not necessarily state or reflect those of the United States Government or any agency thereof. 


\section{$\mathrm{CO}_{2}$ HUFF-n-PUFF PROCESS \\ IN A LIGHT OIL \\ SHALLOW SHELF CARBONATE RESERVOIR}

(No. DE-FC22-94BC14986--16

\section{QUARTERLY TECHNICAL PROGRESS REPORT}

Texaco Exploration \& Production Inc.

P.O. Box 3109

Midland, TX 79702

Date of Report:

Award Date:

Anticipated Completion Date:

DOE Obligation/Award (current year):

Program Manager:

Principal Investigator(s):

Contracting Officer's Representative (COR):

Reporting Period:
06-30-97

02-10-94

12-31-97

$\$ 345,778.00$

Scott C. Wehner

Scott Wehner

Mark Kovar

Jerry Casteel / BPO

$2^{\text {nd }}$ Qtr. 1997 


\section{LEGAL NOTICE/DISCLAIMER}

This report was prepared by Texaco Exploration and Production Inc. (TEPI) pursuant to a Cooperative Agreement partially funded by the U. S. Department of Energy (DOE), and neither TEPI nor any of its subcontractors nor the DOE, nor any person acting on behalf of either:

(A) Makes any warranty or representation, express or implied, with respect to the accuracy, completeness, or usefulness of the information contained in this report, or that the use of any information, apparatus, method, or process disclosed in this report may not infringe privatelyowned rights; or

(B) Assumes any liabilities with respect to the use of, or for damages resulting from the use of, any information, apparatus, method or process disclosed in this report.

References herein to any specific commercial product, process, or service by trade name, trademark, manufacturer, or otherwise, does not necessarily constitute or imply its endorsement, recommendation, or favoring by the DOE. The views and opinions of authors expressed herein do not necessarily state or reflect those of the DOE. 


\section{OBJECTIVES}

The principal objective of this $\mathrm{CO}_{2}$ Huff-n-Puff (H-n-P) project is to determine the feasibility and practicality of the technology in a waterflooded shallow shelf carbonate environment. The results of parametric simulation of the $\mathrm{CO}_{2} \mathrm{H}-\mathrm{n}-\mathrm{P}$ process, coupled with the Central Vacuum Unit (CVU) reservoir characterization components will be used to determine if this process is technically and economically feasible for field implementation. The technology transfer objective of the project is to disseminate the knowledge gained through an innovative plan in support of the Department of Energy's (DOE) objective of increasing domestic oil production and deferring the abandonment of shallow shelf carbonate (SSC) reservoirs. Tasks associated with this objective are carried out in what is considered a timely effort for near-term goals.

\section{BACKGROUND}

Texaco Exploration and Production Inc's. (TEPI) has mid-term plans are to implement full-scale miscible $\mathrm{CO}_{2}$ projects in the Permian Basin of West Texas and Southeast New Mexico. The economic market precludes acceleration of many such capital intensive projects in many cases. This is a common finding throughout the Permian Basin SSC reservoirs. In theory, it is believed that the "immiscible" $\mathrm{CO}_{2} \mathrm{H}-\mathrm{n}-\mathrm{P}$ process might bridge these longer-term "miscible" projects with near-term results. A successful implementation would result in near-term production, or revenue, to help offset cash outlays during the initial startup of a miscible flood. The DOE partnership provides some relief to the associated R \& D risks, allowing TEPI to evaluate a proven Gulf-coast sandstone technology in a waterflooded carbonate environment. Numerous sites exist for widespread replication of this technology following a successful field demonstration.

TEPI concluded all of the Tasks associated with the First Budget Period by October, 1995. The DOE approved the TEPI continuation application. Budget Period No. 2 is in progress. Initial injection of $\mathrm{CO}_{2}$ began in November, and after a short shut-in period for the soak, the well was returned to production in late December, 1995. Monitoring the results of the first demonstration continued through mid-year 1996. This report identifies a new site where the demonstration project is progressing.

\section{SUMMARY of TECHNICAL PROGRESS}

\section{FIELD DEMONSTRATION:}

Results from Initial Demonstration Site. The $\mathrm{CO}_{2}$ Huff-n-Puff process has not met with successful results at the initial demonstration site at CVU. As mentioned in the previous report, there are several reasons contemplated as to the reasons behind the results. Most noteable is the fact that other San Andres locations which have been operating Water-Alternating Gas injection have seen marked reductions in injectivity on the water cycle, while operators within the Vacuum field have not. If there is a relation, as hypothesized in some industry literature, then rather than conclude this demonstration with inconclusive results, TEPI proposed further investigations. The Vacuum reservoir may not be amenable to trapping of $\mathrm{CO}_{2}$ gas in the matrix.

New Site. A new demonstration site at the Sundown Slaughter Unit (SSU) in Hockley County, Texas has been approved by the DOE. SSU is also a shallow shelf carbonate reservoir that is currently under miscible $\mathrm{CO}_{2}$ injection in the Eastern portions of the field. The final demonstration cycles of this project would be conducted in the western portion of the SSU where $\mathrm{CO}_{2}$ flooding operations have not yet been expanded, therefore having no influence on production. Miscible injection operations in this field have experienced the 
reduced injectivity with $\mathrm{CO}_{2} \mathrm{WAG}$ operations as similarly seen elsewhere within the Permian Basin. The very pronounced injection hysteresis effects experienced at SSU suggest the ability for $\mathrm{CO}_{2}$ to form a nearwellbore gas saturation. A field map showing the demonstration site, well number 1341, and current miscible flood operations is provided as Fig. 1.

Well 1341 was drilled in 1984 and cased with five and one-half inch casing to TD at 5032'. The San Andres Formation was perforated over a fifty-three foot interval with 2 jet-shots per foot. The primary criteria in choosing a Huff-n-Puff candidate at SSU included, (1) reservoir quality as indicated by porosity-feet of pay and offset well performance; (2) casing condition; many wells at SSU have had casing leaks, particularly the older wells; (3) proximity to an existing pipeline source of $\mathrm{CO}_{2}$; (4) current production rate. It was felt that a high total fluid rate indicated good permeability. A low oil cut was desirable since any incremental oil produced could be considered tertiary oil, and parametric simulations suggested better recoveries making it easier to evaluate the success of the project; and (5) proximity to existing horizontal wells and $\mathrm{CO}_{2}$ injectors that might cause interference. Texaco did not want any abnormal influences affecting the results of the test. $\mathrm{CO}_{2}$ injection for the Sundown Slaughter demonstration site began on June 16, 1997 in well No. 1341. Through June 30, 1997, a total of 9.7 MMscf has been injected into the first demonstration site at SSU. It is planned that a total of 50 MMscf of $\mathrm{CO}_{2}$ be injected into well No. 1341 .

\section{REFERENCES/PUBLICATIONS}

The Petroleum Recovery Research Center continues to provide updates on the project in its quarterly newsletter. In addition, the Petroleum Technology Transfer Counsel, a joint venture between the Independent Producers Association of America (IPAA) and DOE is providing complete quarterly and annual Technical Reports on an Industry Bulletin Board called GO-TECH. This is allowing a more timely dissemination of information to interested parties.

A review of the project performance and results to date was presented in Houston, Texas on June 18, 1997 at a Department of Energy Contract Review meeting. The meeting was highly attended by industry representatives. 


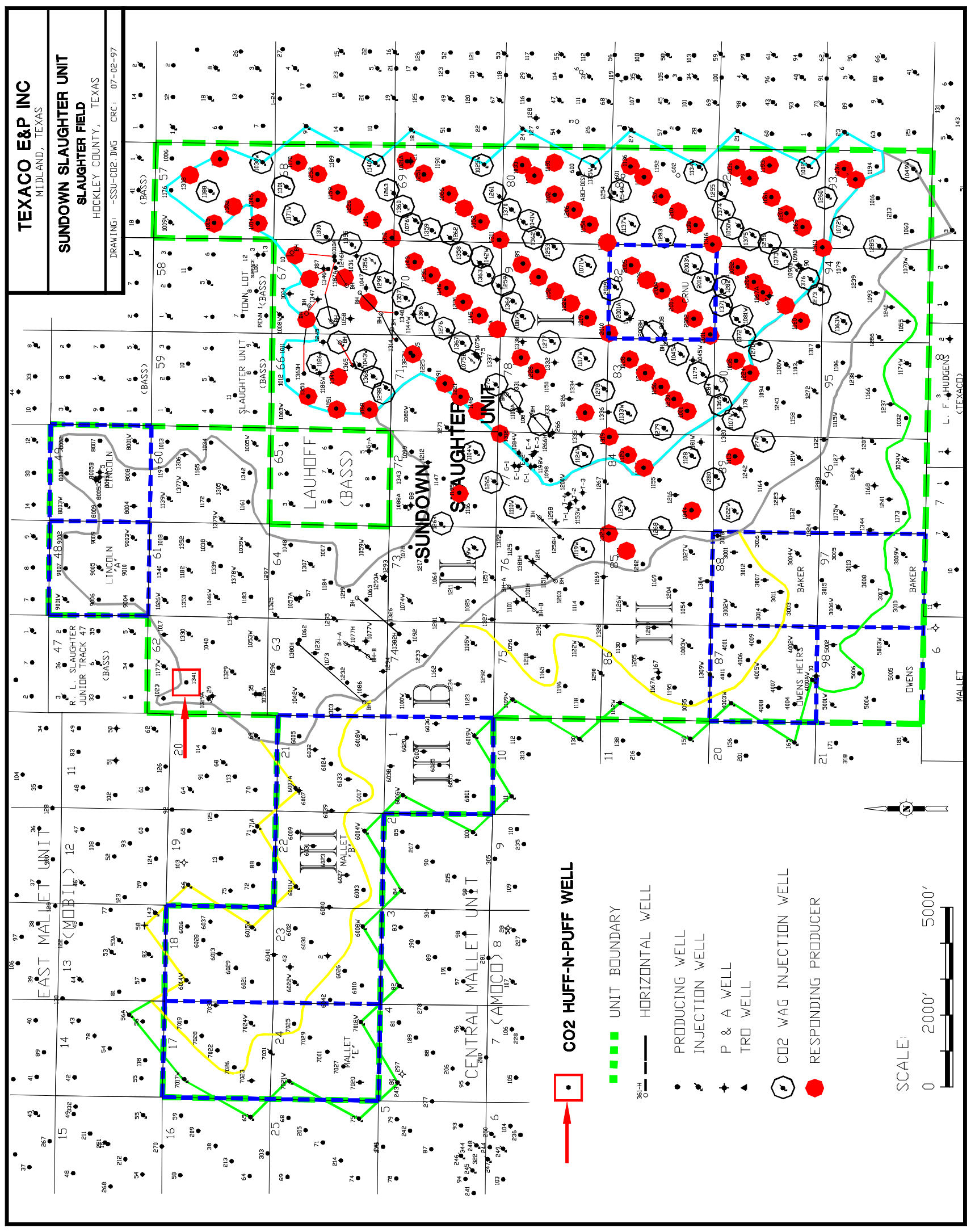

